\title{
PENGARUH PELATIHAN PROFESI GURU TERHADAP PRESTASI KERJA GURU PADA SEKOLAH MENENGAH KEJURUAN 02 BATU
}

\author{
Unggul Bayu Aji \\ Program Studi Manajemen FEB UMM \\ E-mail: unggulbayu@gmail.com
}

\begin{abstract}
This watchfulness aim is that is: 1) to describe teacher profession training that carried out. 2) to describe teacher labour capacity level. 3) to analyze signifikansi teacher profession training variable influence towards teacher labour capacity. this watchfulness use is especially for school that is upon which input (input) to increase civil public servant labour capacity in teacher.

Based on watchfulness result and discussion that done so can be pulled conclusion that teacher profession training that carried out in country vocational high school 02 stones enters in good category. teacher labour capacity in country vocational high school 02 Batu enters in tall category and influential teacher profession training significant towards teacher labour capacity in country vocational high school 02 Batu.

Suggestion that can be submitted in this watchfulness that is supposed school management side always cope to give input to training administrator side on the chance of matter that given can correctly as according to need level teachers perserta training. training matter that given genuinely can to increase teacher ability at the area and education official or administrator institution always cope to maximise potential teachers passes training activity that is by using instructor genuinely has ability at the area each.
\end{abstract}

Keywords: Training, Teacher Labour Capacity

\section{PENDAHULUAN}

Guru sebagai tenaga pendidikan memiliki peranan penting dalam mencerdaskan kehidupan masyarakat. Karena itu, profesional guru sangat diperlukan untuk meningkatkan kualitas pendidikan yang sangat berhubungan dengan membangun fondasi dari pembentukan sumber daya manusia. Sehingga guru sebagai salah satu unsur dibidang pendidikan harus berperan aktif dalam menetapkan kedudukanya sebagai tenaga profesional, sesuai dengan tuntutan masyarakat yang semakin berkembang. Dapat dikatakan bahwa pada setiap guru terletak tanggung jawab untuk membawa para siswanya pada suatu kedewasaan atau taraf kematangan tertentu, yang berarti suatu pernyataan yang kompleks didalam suatu organisme yang mengarahkan tingkah laku terhadap tujuanya. Hal ini menunjukkan betapa pentingnya posisi guru dalam dunia pendidikan sehingga selayaknya guru memiliki prestasi kerja yang baik. (www.wikipedia.org.

Prestasi kerja adalah suatu hasil kerja yang dicapai oleh seseorang dalam melaksanakan tugastugas yang dibebankan kepadanya yang didasarkan atas kecakapan, pengalaman dan kesungguhan serta waktu. Hasibuan (2005) Prestasi kerja seorang guru dapat berupa mengikuti lomba atau membuat karya ilmiah, misalnya melakukan penelitian tentang cara mengajar yang efektif, guru yang mempunyai pengetahuan lebih dari pada guru yang lain dapat menjadi pembicara dalam seminar dan membuat buku penunjang pelajaran, dimana 
ini adalah suatu prestasi yang belum tentu semua orang bisa melakukanya. (Diknas, 2000) Perubahan perubahan yang akan datang menghendaki adanya strategi yang menuntut pelatihan sumber daya manusia untuk perbaikan prestasi kerja yang ada saat ini dan juga dalam mengantisipasi kebutuhan kebutuhan yang akan datang. (Alwi, 2001).

Simamora dan Kamil (2010) mengemukakan bahwa pelatihan sebagai serangkaian aktivitas yang dirancang untuk meningkatkan keahlian keahlian, pengetahuan, pengalaman, ataupun perubahan sikap seorang individu. Pelatihan menurut Simamora diartikan sebagai aktivitas yang dirancang untuk meningkatkan pengetahuan, pengalaman dan keterampilan agar individu dapat berubah sikapnya. Pelatihan Profesi Guru merupakan serangkaian dari sertifikasi guru dalam jabatan setelah melalui proses penilaian portofolio. Di samping itu, menurut Samami dkk. (2006), yang perlu disadari adalah bahwa guru adalah subsistem pendidikan nasional. Dengan adanya pelatihan profesi guru, diharapkan kompetensi guru sebagai agen pembelajaran akan meningkat sesuai dengan standar yang telah ditetapkan. Dengan kompetensi guru yang memenuhi standar minimal dan kesejahteraan yang memadai diharapkan prestasi kerja guru dalammengelola proses pembelajaran dapatmeningkat.

Dengan adanya pelatihan profesi guru tersebut maka akan menghasilkan (guru) Pegawai Negeri Sipil yang berkualitas dan mampu memberikan kontribusi yang terbaik dalam pencapaian tujuan. Melalui pelatihan ini juga instansi pendidikan atau sekolah dapat memiliki pegawai (guru) yang memiliki kompetensi untuk bersaing. Sebagaimanifestasi dari fungsi pengembangan kualitas pada guru, maka guru yang dimiliki sekolah tersebut harus diberi pelatihan profesi guru dengan baik untuk melanjutkan sertifikasi. Sertifikasi sebagai upaya peningkatan pembelajaran, layanan bimbingan dan konseling, serta kepengawasan pada satuan pendidikan formal secara berkelanjutan, sesuai dengan Peraturan Menteri Pendidikan Nasional No. 10 Tahun 2009. Pelatihan profesi guru adalah bagian dari pendidikan yang dilakukan bagi guru untuk meningkatkan pengetahuan dan keterampilanya sesuai dengan tuntutan persyaratan pembiayaanya sebagai
Pegawai Negeri Sipil pada guru. Mengingat pentingnya pengaruh pelatihan untuk meningkatkan prestasi kerja guna mencapai tujuan instansi pendidikan atau sekolah.

\section{TINJAUAN PUSTAKA}

Penelitian terdahulu yang dilakukan oleh Yuniardi (2008) dengan judul "Pengaruh Pelatihan Terhadap Prestasi Kerja Pegawai” (Studi Pada Pusat Pengembangan dan Pemberdayaan Pendidik dan Tenaga Kependidikan Kewarganegaraan dan Ilmu Pengetahuan Sosial/PPPPTK PKN dan IPS Malang) Tujuan penelitian ini adalah untuk membuktikan secara empirik pelatihan secara bersama sama dan sendiri sendiri berpengaruh dan signifikan terhadap prestasi kerja pegawai PPPPTK PKN dan IPS Malang.

Pelatihan didefinisikan sebagai proses belajar mengajar dalam rangka meningkatkan kompetensi. (PP No. 101 Tahun 2000). Menurut Simamora dan Kamil (2010) pelatihan sebagai serangkaian aktivitas yang dirancang untuk meningkatkan keahlian keahlian, pengetahuan, pengalaman, ataupun perubahan sikap seorang individu. Pelatihan menurut Simamora diartikan sebagai aktivitas yang dirancang untuk meningkatkan pengetahuan, pengalaman dan keterampilan agar individu dapat berubah sikapnya.

Selanjutnya, (Edwin B. Filippo dalam Kamil, 2010) memberikan penjelasan mengenai pelatihan adalah tindakan meningkatkan pengetahuan dan keterampilan seorang pegawai untuk melaksanakan pekerjaan tertentu. Definisi pelatihan ini diartikan sebagai upaya peningkatan keterampilan terhadap pegawai yang bertujuan agar dapat melaksanakan tugas/pekerjaan tertentu. Menurut Andrew E. Sikula yang dikutip oleh Anwar Prabu Mangkunegara (2000) mengemukakan bahwa pelatihan (training) adalah "suatu proses pendidikan jangka pendek yang mempergunakan prosedur sistematis dan terorganisasi dimana pegawai non manajerial mempelajari pengetahuan dan keterampilan teknis dalam tujuan yang terbatas". Sedangkan Rivai dan Sagala (2010) pelatihan merupakan bagian pendidikan yang menyangkut proses belajar 
untuk memperoleh dan meningkatkan keterampilan diluar sistem pendidikan yang berlaku dengan relatif singkat dengan metode yang lebih mengutamakan praktek dari pada teori.

Suatu perusahaan/ instansi yang sebagian besar pegawainya mempunyai kecakapan, keterampilan dan pengetahuan yang tinggi, maka prestasi kerja akan meningkat. Untuk mewujudkan hal tersebut, maka pelaksanaan program pelatihan secara tepat dan terencana. Pada dasarnya pelatihan karyawan merupakan suatu usaha untuk meningkatkan kualitas serta kemampuan pegawai dalam prestasi kerja. Pelatihan biasanya terfokus pada penyediaan bagi para pegawai keahlian keahlian khusus atau membantu mereka mengoreksi kelemahan kelemahan dalam prestasi kerja mereka, sehingga melalui pelatihan dilakukan segenap upaya dalam rangka meningkatkan prestasi kerja pegawai pada pekerjaan yang diduduki sekarang (Simamora, 2001) Selain itu tujuan pelatihan adalah membuat pegawai bereaksi dalam cara tertentu tanpa ragu ragu. Sedangkan prestasi kerja adalah hasil yang dicapai seorang pegawai dalam melaksanakan tugas dan tanggung jawab yang dibebankan kepadanya. Dengan demikian pelatihan berguna untuk membantu pegawai dalam memahami suatu pengetahuan praktis dan penerapannya, guna meningkatkan ketrampilan, kecakapan dan sikap yang diperlukan oleh organisasi dalam usaha mencapai tujuan.

Secara rinci tujuan pelaksanaan pelatihan bagi karyawan dikemukakan oleh Simamora (2001) bahwa terdapat tujuh bidang yang merupakan tujuan utama pelatihan yaitu: 1) Memperbaiki Kinerja, 2) Memutakhirkan keahlian para pegawai sejalan dengan kemajuan teknologi, 3) Mengurangi waktu belajar bagi pegawai baru supaya menjadi kompeten dalam pekerjaan, 4) Membantu memecahkan permasalahan operasional, 5) Mempersiapkan pegawai untuk promosi, 6) Mengorientasikan pegawai terhadap perusahaan, 7) Memenuhi kebutuhan pertumbuhan diri.

Menurut Umar Hamalik (2001) dan Gomes (2002) faktor faktor yang perlu diperhatikan dalam pelatihan adalah sebagai berikut: 1)Peserta pelatihan, 2)Pelatih/Instruktur, 3) Lamanya pelatihan,
4) Media (bahan pelatihan), 5) Metode pelatihan. Lebih lanjut menurut Mangkunegara (2001) faktor faktor yang perlu diperhatikan dalam pelatihan adalah sebagai berikut: 1) Perbedaan individu pegawai, 2) Hubungan dengan analisis jabatan, 3) Motivasi, 4) Seleksi peserta penataran, 5) Metode pelatihan.

Pada dasarnya prestasi kerja itu mencakup kecakapan, keterampilan, pengalaman maupun memanfaatkan waktu secara efisien, bertanggung jawab terhadap tugas, hasil kerja melebihi yang ditentukan. Dimana kinerja sering juga diartikan sebagai prestasi kerja, sehingga memberikan pengertian prestasi kerja adalah kemampuan seseorang didalam menyelesaikan pekerjaan (Thoha, 2000). Menurut Sinungan (2000), prestasi kerja merupakan bagian penting dari seluruh proses kekayaan karyawan yang bersangkutan. Pentingnya penilaian yang rasional dan diterapkan secara objektif terlihat pada paling sedikit dua kepentingan yaitu kepentingan karyawan yang bersangkutan dan kepentingan organisasi.

Berdasarkan pengertian diatas dapat diketahui bahwa prestasi kerja adalah produk dan jasa yang dihasilkan dari serangkaian aktivitas baik individu maupun kelompok dalam suatu proses kerja karyawan dimana hasil kerja tersebut sesuai dengan standart dan ketentuan yang telah ditetapkan. Menurut Martoyo (2000), faktor-faktor yang mempengaruhi prestasi kerja karyawan adalah motivasi, kepuasan kerja, kondisi fisik pekerjaan, dan kemampuan. Adapun penjelasan yakni ; 1) Motivasi, 2) Kepuasan kerja, 3) Kondisi fisik pekerjaan, dan 4) Kemampuan.

Berdasarkan pengertian pengertian diatas, maka dapat dimengerti bahwa apabila dalam suatu perusahaan/ instansi yang sebagian besar pegawainya mempunyai kecakapan, keterampilan dan pengetahuan yang tinggi, maka prestasi kerja akan meningkat. Untuk mewujudkan hal tersebut, maka pelaksanaan program pelatihan secara tepat dan terencana. Pada dasarnya pelatihan karyawan merupakan suatu usaha untuk meningkatkan kualitas serta kemampuan pegawai dalam prestasi kerja. Pelatihan biasanya terfokus pada penyediaan bagi para pegawai keahlian keahlian khusus atau mem- 
bantu mereka mengoreksi kelemahan kelemahan dalam prestasi kerja mereka, sehingga melalui pelatihan dilakukan segenap upaya dalam rangka meningkatkan prestasi kerja pegawai pada pekerjaan yang diduduki sekarang (Simamora, 2001).

Jadi, pada akhirnya teknik (metode) yang merupakan landasan yang tepat dalam meningkatkan prestasi kerja pegawai adalah mengadakan pelatihan.

\section{METODE PENELITIAN}

Penelitian dilakukan pada Sekolah Menengah Kejuruan Negeri 02 Batu yang berlokasi di Jalan Raya Pandanrejo No.39 A Bumiaji Kota Batu. Jenis penelitian yang dilakukan adalah survei, dimana informasi yang dikumpulkan dari responden dengan menggunakan kuesioner. Populasi dalam penelitian ini adalah seluruh (Guru) Pegawai Negeri Sipil di SMK Negeri 02 Batu yang sudah mengikuti pelatihan profesi guru sebanyak 40 orang. Sampel adalah bagian dari jumlah karakteristik yang dimiliki populasi, (Sugiyono, 2005) menyatakan apabila jumlah subyek kurang dari 100 maka lebih baik diambil semua. Sampel yang digunakan dalam penelitian ini adalah seluruh jumlah populasi yang ada yaitu 40 guru di Sekolah Menengah Kejuruan Negeri 02 Batu. Maka teknik yang digunakan dalam penelitian ini menggunakan total sampling dengan mengambil keseluruhan dari jumlah guru yang sudah mengikuti pelatihan profesi guru.

Jenis dan sumber data yang digunakan adalah data primer dan data sekunder. Data primer merupakan data yang pertama kali di ambil langsung dari sumber, belum melalui proses pengumpulan dari pihak lain. Data primer dalam penelitian ini berupa data jawaban responden pada kuesioner yang di sebarkan peneliti yang berisi pertanyaan mengenai pelatihan profesi guru dan prestasi kerja guru di Sekolah Menengah Kejuruan Negeri 02 Batu. Sedangkan data sekunder adalah sumber data yang diperoleh dari sumber lain dengan cara bertanya guna mencari tambahan data. Data ini meliputi data tentang profil sekolah, visi dan misi sekolah, struktur organisasi, jumlah guru dan karyawan dan data yang terkait dengan pelatihan dan prestasi kerja guru.
Teknik pengumpulan data yang digunakan adalah kuesioner, dan wawancara. Teknik analisis data dalam penelitian ini dengan menggunakan regresi linier sederhana. Rentang skala adalah alat analisis yang digunakan untuk mengetahui rentang antar masing masing kriteria penilaian yaitu pelatihan profesi guru dan prestasi kerja guru dengan menggunakan alat analisis perhitungan rentang skala. Uji hipotesis menggunakan uji F yaitu untuk menguji pengaruh akan signifikansi secara simultan atau bersama sama antara variabel independen terhadap variabel dependen.

\section{HASIL PENELITIAN DAN PEMBAHASAN}

Dalam upaya untuk meningkatkan prestasi kerja guru pada Sekolah Menengah Kejuruan Negeri 02 Batu maka salah satu kebijakan yang diambil yaitu dengan mengikutsertakan para guru atas kegiatan pelatihan yang dilakukan. Mengenai materi pelatihan yang diberikan selama ini para guru selalu disesuaikan dengan kompetensi dasar guru yang meliputi: kompetensi di pedagogik, kompentensi profesional, kompetensi sosial dan kompentensi kepribadian.

Tanggapan responden atas kegiatan pelatihan yang dilakukan selama ini masuk dalam kategori baik. Kategori baik tersebut terkait dengan bentuk pelatihan yang dilakukan di Sekolah Menengah Kejuruan Negeri 02 Batu selama ini yaitu mengenai Pelatihan Profesi Guru diselenggarakan selama 10 hari dan bobot 90 Jam Pertemuan (JP), dengan alokasi 46 JP teori dan 44 JP praktik. Satu JP setara dengan 50 menit. Bentuk-bentuk kegiatan pelatihan yang dilakukan yaitu berupa pelatihan kompetensi guru dan pelatihan alih fungsi guru yaitu terkait dengan proses pembelajaran para guru. Selain itu dalam Undang-Undang no 20 tahun 2003 tentang Sisdiknas pasal 40, hak dan kewajiban guru adalah menciptakan suasana pendidikan yang bermakna, menyenangkan, kreatif, dinamis, dan logis; mempunyai komitmen secara profesional untuk meningkatkan mutu pendidikan; dan memberi teladan dan menjaga nama baik lembaga, profesi, dan kedudukan sesuai dengan kepercayaan. Beberapa kewajiban tersebut terkait secara langsung dengan 
prestasi para guru dalam memberikan pembelajaran di sekolah.

Pada saat proses memberikan pelatihan dapat diketahui bahwa satu kelompok peer teaching/ peer counseling/peer supervising difasilitasi oleh satu orang instruktur yang memiliki Nomor Induk Assesor (NIA) yang berpengalaman menjadi widyaiswara minimal selama 10 tahun pada saat memberikan pelatihan kepada para guru. Dalam proses pembelajaran, instruktur menggunakan multi media dan multi metode yang berbasis pembelajaran aktif, inovatif, kreatif, efektif, dan menyenangkan (PAIKEM) Upaya terkait dengan kegiatan pelatihan tersebut telah dirasakan baik oleh guru baik secara kualitas dan kuantitas atas kegiatan pelatihan yang dilakukan. Hasil baik tersebut juga diikuti dengan adanya peningkatan atas prestasi kerja yang dicapai oleh guru, adapun secara lengkap hasil hasil prestasi kerja para guru mulai tahun 2007 sampai 2011 dapat disajikan pada tabel 1.

Berdasarkan tabel. 1 menunjukkan adanya peningkatan atas hasil prestasi kerja guru yang ditunjukkan dengan adanya peningkatan karya ilmiah, modul dan LKS yang dihasilkan para guru. Selain itu adanya tanggapan yang baik para guru tersebut diikuti dengan adanya peningkatan atas pencapaian prestasi para guru dalam malaksanakan kegiatan belajar mengajar. Pencapaian atas prestasi kerja juga menunjukkan adanya peningkatan, dimana para guru pada Sekolah Menengah Kejuruan Negeri 02 Batu mampu mencapai prestasi dalam kegiatan inovasi Pembelajaran dari Dinas pendidikan, keratifitas mengajar, menjadi pemenang dalam lomba Keberhasilan Guru dalam pembelajaran yang diadakan Dinas pendidikan, terpilih menjadi guru berprestasi dan guru teladan dari Dinas Pen- didikan, Lomba Inovasi pembelajaran dan menjadi guru kreatif dari Dinas Pendidikan Jawa Timur serta Konferensi Guru sejatim menjadi Pemakalah Terpilih. Beberapa prestasi tersebut telah dicapai pada guru Sekolah Menengah Kejuruan Negeri 02 Batu setelah mengikuti kegiatan pelatihan.

Hasil prestasi kerja yang meningkat dapat ditunjukkan dengan adanya peningkatan tingkat kreatifitas guru yaitu dengan adanya kemampuan para guru dalam proses penysunan modul dan buku penunjang pelajaran. Peningkatan tersebut juga dapat mencerminkan atas kemampuan dalam melakukan pengelolaan atas kreatifitas yang dimiliki sehingga mendukung proses peningkatan prestasi kerja para guru. Selajutnya mengenai ketepatan waktu mengajar dapat diketahui bahwa selama ini para guru memiliki kedisiplinan yang tinggi dalam melaksanakan proses pembelajaran di sekolah. Ketepatan tersebut juga menunjukkan jaminan bahwa para guru selalu berupaya untuk memberikan yang terbaik kepada para siswa dalam belajar di sekolah.

Hasil prestasi kerja yang tinggi tersebut juga dapat diketahui dengan frekuensi dalam membuat dan mengkuti lomba karya ilmiah. Adanya frekuensi peningkatan tersebut menunjukkan bahwa selama ini para guru selalu berupaya untuk melakukan perbaikan atas kemampuan para guru untuk melakukan penyusunan karyawan ilmiah dan selalu mengikuti lomba yang terkait dengan lomba yang diselenggarakan oleh Dinas Pendidikan Kota Batu.

Tingkat pengetahuan guru dapat dapat diketahui dari setiap inovasi yang dilakukan yaitu dengan meraka selalu mengikuti workshop dan pernah menjadi pembicara dalam seminar di Universitas Brawaijaya yang dilakukan pada tanggal 22-24 Mei

Tabel 1. Hasil Prestasi Kerja Guru Tahun 2007 Sampai 2011

\begin{tabular}{cccc}
\hline Tahun & Karya IImiah & Modul & LKS \\
\hline 2007 & 5 & 12 & 16 \\
2008 & 11 & 19 & 19 \\
2009 & 13 & 24 & 23 \\
2010 & 15 & 29 & 27 \\
2011 & 19 & 33 & 39 \\
\hline
\end{tabular}

Sumber: Sekolah Menengah Kejuruan Negeri 02 Batu 
1012 terkait dengan keamanan pangan. Hasil analisis menunjukkan bahwa adanya pengaruh antara kegiatan pelatihan dengan prestasi kerja para guru, kondisi tersebut dapat dikatakan bahwa semakin baik kegiatan pelatihan yang dilakukan maka semkain meningkat atas pencapaian prestasi kerja para guru. Hasil penelitian ini didukung oleh teori yang dikemukakan oleh (Simamora, 2001) Pelatihan biasanya terfokus pada penyediaan bagi para pegawai keahlian keahlian khusus atau membantu mereka mengoreksi kelemahan kelemahan dalam prestasi kerja mereka, sehingga melalui pelatihan dilakukan segenap upaya dalam rangka meningkatkan prestasi kerja pegawai pada pekerjaan yang diduduki sekarang. Hasil penelitian ini juga mendukunghasil penelitian terdahulu yang dilakukan oleh Yuniardi (2008) yang menyatakan bahwa terdapat pengaruh antara pelatihan terhadap prestasi kerja.

\section{SIMPULAN}

Pelatihan profesi guru yang dilaksanakan pada Sekolah Menengah Kejuruan negeri 02 Batu masuk dalam kategori baik. Prestasi kerja guru pada Sekolah Menengah Kejuruan Negeri 02 Batu masuk dalam kategori tinggi. Berdasarkan hasil analisis regresi linier sederhana dapat diketahui bahwa pelatihan profesi guru berpengaruh signifikan terhadap prestasi kerja guru pada Sekolah Menengah Kejuruan Negeri 02 Batu. Prestasi kerja yang tinggi dapat ditunjukkan dengan adanya peningkatan tingkat kreatifitas guru yaitu dengan adanya kemampuan para guru dalam proses penysunan modul dan buku penunjang pelajaran. Peningkatan tersebut juga dapat mencerminkan atas kemampuan dalam melakukan pengelolaan atas kreatifitas yang dimiliki sehingga mendukung proses peningkatan prestasi kerja para guru. Selajutnya mengenai ketepatan waktu mengajar dapat diketahui bahwa selama ini para guru memiliki kedisiplinan yang tinggi dalam melaksanakan proses pembelajaran di sekolah. Ketepatan tersebut juga menunjukkan jaminan bahwa para guru selalu berupaya untuk memberikan yang terbaik kepada para siswa dalam belajar di sekolah.

\section{DAFTAR PUSTAKA}

Departemen Pendidikan dan Kebudayaan. 2005. Kamus Besar Bahasa Indonesia, Edisi 3. Balai Pustaka Jakarta.

Danim, S. 2002. Inovasi pendidikan dalam upaya peningkatan profesionalisme tenaga kependidikan. Pustaka Setia. Bandung.

Gomes, Faustimo Cardoso. 2003. Manajemen Sumber Daya Manusia. Andi Offset. Yogyakarta.

Hamalik, Oemar. 2001. Pengembangan Sumber Daya Manusia-Manajeman Pelatihan ketenagakerjaan. BumiAksara. Jakarta.

Hasibuan, Malayu, S.P. 2002. Manajemen Sumber Daya Manusia. Cetakan Kelima Edisi Revisi. BumiAksara. Jakarta.

Handoko, Hani. 2002. Manajemen Personalia. BPFE. Yogyakarta.

Hariandja, Marihot, T.E. 2002. Manajemen Sumber Daya Manusia. Grasindo. Jakarta.

Umar, Husein. 2001. Riset Sumber Daya Manusia Dalam Organisasi, Edisi Revisi. PT Gramedia Pustaka Utama. Jakarta.

Mangkunegara, A. Prabu. 2005. Evaluasi Kinerja SDM. Refika Aditama. BPFE. Bandung.

Martoyo, Susilo. 2000. Manajemen Sumber Daya Manusia. Edisi Keempat. Yogyakarta.

Mathis L. Robert, dan Jackson H.J. 2004. Manajemen Sumber Daya Manusia. Salemba Empat. Jakarta.

Mulyasa. 2005. Menjadi guru profesional. PT.Remaja Rosda Karya. Bandung.

Nazir.2009. Metode Penelitian. Ghalia Indonesia. Bogor.

Peraturan pemerintah No. 19 tahun 2005 tentang standart nasional pendidikan. Jakarta: departemen pendidikan nasional.

Poerwono, Hadi. 2002. Tata Personalia, Djambatan, Edisi ke-III. Jakarta.

Ranupandoyo, dan Suad Husnan. 2000. Manajemen Personalia. Fakultas Ekonomi UGM (BPFE). Yogyakarta. 
100 Jurnal Manajemen Bisnis • Volume 3 No. 01 • Edisi April 2013

Sulistiyani, Ambar Teguh dan Rosidah. 2003. Manajemen Sumber Daya Manusia. Graha Sugiyono. 2009. Metode Penelitian Ilmu. Yogyakarta. Administrasi. Alfabeta. Bandung.

Syuhada. 2005. Model Pendidikan dan Pelatihan: Teori dan Aplikasi. Erlangga.

Jakarta. 